\title{
ANALISIS POTENSI PENGEMBANGAN DESTINASI WISATA HALAL DI KOTA BATAM
}

\author{
Taufiq Hidayat ${ }^{1}$ \\ Dosen STIEPAR YAPARI, Bandung \\ taufiqhi7912@gmail.com \\ Taufik Hidayat ${ }^{2}$ \\ Mahasiswa STIEPAR YAPARI, Bandung \\ thidayat850@yahoo.com
}

\begin{abstract}
Penelitian ini dimaksudkan untuk menganalisis dan mengkaji potensi dan pengembangan wisata halal di Kota Batam sesuai dengan kriteria wisata halal yang dikembangkan oleh kementrian pariwisata. Pengumpulan data dilakukan dengan observasi, wawancara mendalam, studi literature, dan quesioner dengan Dinas Pariwisata dan Kebudayaan Kota Batam, ASITA, PHRI, HPI, Majelis Ulama Indonesia Kota Batam, dan wisatawan. Pendekatan dalam penelitian ini menggunakan pendekatan kualitatif dengan metode analisis yang digunakan menggunakan analisis SWOT (strength, weakness, opportunity, threat).

Hasil penelitian menunjukan potensi pengembangan destinasi wisata halal di kota Batam dilihat dari aspek atraksi, aksesibilitas, amenitas dan kelembagaan pariwisata seluruhnya sudah dalam kondisi yang baik dan siap mendukung pengembangan destinasi wisata halal di Kota Batam. Hadirnya wacana pengembangan wisata halal direspons sangat baik oleh para pelaku industri pariwisata, tokoh agama dan masyarakat Kota Batam karena dianggap memiliki prospek yang menjanjikan sekaligus mampu membawa nilai-nilai kebaikan. Dibutukan komitmen dan koordinasi dengan berbagai pihak dan harus didukung pula dengan kesiapan sumber daya manusia yang berkompeten di bidang pariwisata serta melakukan pemasaran yang tepat agar pengembangan wisata halal di Kota Batam berjalan secara optimal.
\end{abstract}

Kata kunci: Potensi, Pengembangan Destinasi, Wisata Halal 


\title{
THE ANALYSIS OF POTENCY OF HALAL TOURISM DESTINATION DEVELOPMENT IN BATAM CITY
}

\begin{abstract}
This research is intended to analyze and assess the potential and development of halal tourism in Batam City in accordance with the criteria of halal tourism developed by the ministry of tourism. The data was collected by observation, indepth interview, literature study, and quesioner with Batam Tourism and Culture Office, ASITA, PHRI, HPI, Majelis Ulama Indonesia Kota Batam and tourists. Approach in this research using qualitative approach with analysis method used by SWOT analysis (strength, weakness, opportunity, threat). The research results show the potential for the development of halal tourism destination in the city of Batam viewed from the aspect of attraction, accessibility, amenitas and institutional tourism are all in good condition and ready to support the development of halal tourism destination in Batam. The presence of the the development of halal tourism was responded very well by the tourism industry, religious leaders and the people of Batam because it is considered to have a promising prospect as well as able to bring good values. Required commitment and coordination with various parties and must be supported also with the readiness of competent human resources in the field of tourism and do the right marketing for the development of halal tourism in Batam is running optimally.
\end{abstract}

Keywords: Potency, Development of destination, Halal Tourism

\section{PENDAHULUAN}

Pariwisata menjadi salah satu sektor unggulan dalam upaya pemerintah baik pusat maupun daerah dalam memperoleh pendapatan daerah serta negara. Pariwisata menjadi faktor kunci dalam pendapatan, penciptaan lapangan kerja, pengembangan usaha serta infrastruktur. Banyaknya keuntungan dari kegiatan pariwisata ini mengakibatkan banyaknya destinasi pariwisata yang baru dikembangkan untuk menarik wisatawan dan dipasarkan tidak hanya secara regional, nasional, ataupun internasional. Organisasi Pariwisata Dunia (UNWTO, 2016), menyebutkan bahwa ada sekitar 1,186 miliar wisatawan mancanegara yang melakukan perjalanan selama periode tahun 2015. Jumlah tersebut naik 4,4\% dibanding tahun 2014 dan diprediksi akan terus meningkat setiap tahunnya.

Jumlah pengeluaran wisatawan Muslim dunia pada tahun 2014 sebesar US\$1.8 trilyun dan diproyeksikan akan tumbuh menjadi US\$2.6 trilyun pada tahun 2020 (Sofyan Hospitality's, 2016). Wisatawan Muslim dunia pada tahun 2015 adalah berjumlah 117 juta orang dan akan diprediksi tumbuh menjadi 168 juta orang pada tahun 2020. Wisatawan mancanegara Muslim yang berkunjung ke Indonesia pada tahun 2015 adalah sebanyak 2,2 juta orang dan akan diprediksi tumbuh menjadi 5 juta orang pada tahun 2020. Sedangkan wisatawan nusantara Muslim yang melakukan perjalanan selama periode 2015 berjumlah 225 juta 
perjalanan dan akan diprediksi tumbuh menjadi 260 juta perjalanan pada tahun 2020 (UNWTO Tourism Higlights, 2016).

Saat ini negara-negara yang penduduknya mayoritas non-Muslim sudah banyak yang mengarah pada bagaimana memikat wisatawan Muslim untuk datang ke negara mereka. Thai Airways Catering Service telah menjadi The Biggets Halal Kitchen in The World, Hongkong yang memperbanyak pembangunan masjid, Thailand yang menyediakan tempat shalat berukuran besar di Svarnabhumi International Airport hingga Cina yang gencar mewajibkan kamar hotel dilengkapi dengan penunjuk arah kiblat. Indonesia sebagai negara yang mayoritas penduduknya Muslim sudah seharusnya mengembangkan fasilitas dan pelayanan pariwisata bagi pemenuhan kebutuhan perjalanan wisatawan Muslim.

Bukti keseriusan pemerintah dalam mengembangkan pariwisata halal dalam hal ini kementrian pariwisata adalah dengan telah dibentuknya Tim Percepatan Pengembangan Pariwisata Halal Indonesia, Tim Pemenangan World Halal Travel Award dan penjurian Kompetisi Pariwisata Halal 2016 serta sertifikasi bagi para pelaku industri pariwisata halal. Pengembangan wisata halal oleh Kementerian Pariwisata sejauh ini sudah menunjukan hasil yang cukup memuaskan. Hal tersebut telah terbukti dengan telah diraihnya tiga buah penghargaan halal tingkat dunia yaitu; Lombok sebagai World's Best Halal Tourism Destination, Lombok sebagai World's Best Halal Honeymoon Destination, dan Sofyan Hotel Jakarta sebagai World's Best Family Friendly Hotel.

Kota Batam adalah bagian dari Provinsi Kepulauan Riau yang lokasinya berada pada jalur pelayaran internasional Selat Malaka berbatasan langsung dengan Singapura dan Malaysia, secara geografis lokasi kota Batam sangat strategis dengan kemudahan akses masuk melalui Bandara Internasional Hang Nadim serta tiga pelabuhan domestik dan lima pelabuhan bertaraf internasional menjadikan batam sebagai kota metropolitan. Pengembangan pariwisata Kota Batam sebagai sebuah destinasi wisata halal merupakan respon dari kebijakan kementrian pariwisata yang pada saat ini sedang mengembangkan Top 10 Muslim Friendly Destination di Indonesia antara lain; Nangroe Aceh Darussalam, Sumatera Barat, Riau dan Kepulauan Riau, DKI Jakarta, Jawa Barat, Jawa Tengah, Yogyakarta, Jawa Timur, Nusa Tenggara Barat dan Sulawesi Selatan. Batam telah dipilih oleh Kementerian Pariwisata sebagai salah satu akses gerbang masuk utama wisatawan Muslim mancanegara bersamaan dengan Bali dan Jakarta. Penetapan Great Batam (Klaster: Aceh, Sumatera Barat, Riau dan Kepulauan Riau), merupakan salah satu implementasi dari strategi pemasaran destinasi wisata halal di Indonesia untuk mencapai target kunjungan 20 juta wisatawan mancanegara ke Indonesia pada tahun 2019.

Destinasi pariwisata di Indonesia, secara definisi yang lebih operasional dirumuskan dalam UU No.10 tahun 2009 yang menegaskan bahwa destinasi pariwisata merupakan kawasan geografis yang berada dalam satu atau lebih wilayah administratif yang di dalamnya terdapat daya tarik wisata, fasilitas umum, fasilitas pariwisata, aksesibilitas, serta masyarakat yang saling terkait dan melengkapi terwujudnya kepariwisataan.

Sedangkan menurut Cooper, Flecher, Gilbert, Stepherd and Wanhill (1998) destinasi pariwisata merupakan perpaduan atau brand dari keseluruhan komponen produk, layanan dan pengalaman kunjungan wisata yang dikembangkan dan disediakan di suatu kawasan dengan unsur kelokalannya. 
Cooper (1998) mengatakan suatu destinasi memiliki 6 (enam) unsur pembentukan suatu destinasi wisata yang saling terkait antara lain :

1. Atraksi (attraction), adalah produk utama sebuah destinasi yang berkaitan dengan aktivitas atau kegiatan apa yang dapat dilakukan dan dilihat wisatawan di destinasi tersubut (what to do dan what to see). Pada intinya atraksi wisata terdiri dari semua elemen "nonhome" suatu tempat yang menarik wisatawan bebas dari rumah mereka.

2. Amenitas (amenity), dijelaskan dalam PP no. 50 tahun 2011 tentang Rencana Induk Pengembangan Pariwisata Nasional sebagai fasilitas pariwisata, yaitu semua jenis sarana yang secara khusus ditujukan untuk mendukung penciptaan kemudahan, kenyamanan, keselamatan wisatawan dalam melakukan kunjungan ke destinasi pariwisata meliputi fasilitas penunjang wisata, yaitu : akomodasi, rumah makan, retail, kios cendera mata, biro perjalanan, dan money changer.

3. Aksesibilitas, mencakup sistem transportasi yang meliputi jalur transportasi, fasilitas pelabuhan, bandara, terminal, dan moda transportasi apa untuk menuju destinasi tersebut apakah menggunakan bis, kereta api, dan pesawat. Selain itu juga bagaimana cara wisatawan menuju ke destinasi tersebut apakah menggunakan jalan raya, laut dan udara atau melalui sistem jalan toll.

4. Fasilitas pendukung (ancilary), yaitu fasilitas-fasilitas pendukung yang diperlukan oleh wisatawan selama berada di destinasi wisata seperti bank, dan rumah sakit, toko bebas bea, binatu, pemandu wisata, area festival, fasilitas rekreasi, yang cenderung untuk membantu pengembangan industri pendukung.

5. Aktivitas, meliputi seluruh kegiatan yang dapat dilakukan oleh wisatawan pada destinasi tersebut. World Tourism Organization (WTO) mendefenisikan aktivitas wisata sebagai kegiatan manusia yang melakukan perjalanan (keluar dari lingkungan asalnya) untuk tidak lebih dari satu tahun berlibur, berdagang, atau urusan lainnya.

6. Paket wisata, meliputi paket-paket perjalanan wisata yang diatur dan diselenggarakan oleh biro perjalanan wisata.

\section{Wisata Halal}

Bawazir (2013), mengatakan bahwa wisata halal merupakan perjalanan wisata yang semua prosesnya sejalan dengan nilai-nilai syariah Islam. Baik dimulai dari niatnya semata-mata untuk ibadah dan mengagumi ciptaan Allah, selama dalam perjalanannya dapat melakukan ibadah dengan lancar dan setelah sampai di tujuan wisata, tidak mengarah kepada hal-hal yang bertentangan dengan syariah, makan dan minum yang halalan thayyibah, hingga kepulangannya pun dapat menambah rasa syukur kita kepada Allah.

Chookaew (2015), menyebutkan lebih dalam bahwa konsep wisata halal merupakan Aktualisasi dari konsep Islaman dimana nilai halal dan haram menjadi tolak ukur utama, hal ini berarti seluruh aspek kegiatan wisata tidak terlepas dari sertifikasi halal yang harus menjadi acuan bagi setiap pelaku wisata.

\section{Panduan Umum Destinasi Wisata Halal}

Kriteria dan panduan umum halal yang wajib dipenuhi Sebuah destinasi wisata atau daya tarik wisata yang meliputi alam, budaya, dan buatan manusia, antara lain: 
1. Harus memberikan pencerahan, penyegaran dan ketenangan serta menghindari kegiatan-kegiatan yang mengandung kemusyrikan, khufarat, dan maksiat;

2. Terjaganya keamanan, kenyamanan dan keselamatan serta mewujudkan kebaikan yang bersifat universal dan inklusif;

3. Menghormati nilai-nilai sosial budaya dan kearifan lokal serta pertunjukan seni dan budaya, atraksi maupun tayangan audio visual tidak bertentangan dengan kriteria umum pariwisata halal;

4. Tersedia fasilitas ibadah yang sesuai dengan prinsip halal yaitu mudah dijangkau dan layak pakai serta suci;

5. Tersedia makanan dan minuman halal yang terjamin kehalalannya dengan sertifikat halal yang dikeluarkan oleh Majelis Ulama Indonesia setempat;

6. Terjaga kebersihan sanitasi dan lingkungan di dalam lokasi destinasi wisata maupun sekitarnya.

\section{METODOLOGI}

Penelitian ini menggunakan pendekatan kualitatif untuk mengungkap, memahami, dan menggambarkan realitas dan fenomena yang terjadi di lapangan. Desain penelitian yang digunakan bersifat deskriptif, yang bertujuan untuk menjelaskan, menggambarkan, atau melukiskan secara sistematis, faktual, dan akurat mengenai fakta yang diselidiki.

Dalam penelitian ini, Peneliti akan melakukan teknik pengumpulan data kualitatif secara sistematis dimana semua informasi yang peneliti peroleh dari para informan antara lain Dinas Pariwisata dan Kebudayaan Kota Batam, ASITA, PHRI, HPI, Majelis Ulama Indonesia Kota Batam, dan wisatawan melalui proses wawancara, observasi, studi dokumentasi, serta quesioner semuanya akan direkam, dicatat dan dikumpulkan lalu dikelompokan berdasarkan keperluan dan kebutuhan yang berkorelasi serta mampu menjawab rumusan masalah berdasarkan instrumen pernyataan. Metode analisis data yang digunakan dalam penelitian ini ialah metode menggunakan analisis SWOT (strength, weakness, opportunity, threat).

Data-data yang akan digunakan dalam penelitian ini dapat dikelompokan menjadi dua jenis, yaitu :

1. Data primer, yang diperoleh melalui observasi, wawancara, dan diskusi mendalam dengan instansi terkait dalam hal ini adalah Dinas Pariwisata dan Kebudayaan Kota Batam, Majelis Ulama Indonesia Kota Batam dan beberapa asosiasi pariwisata seperti; Asosiasi Perusahaan Perjalanan Indonesia (ASITA) Provinsi Kepulauan Riau, Perhimpunan Hotel dan Restoran Indonesia Kota Batam dan Himpunan Pramuwisata Indonesia Kota Batam, Serta wisatawan.

2. Data sekunder, yang diperoleh dari jurnal nasional dan internasional, majalah Halal Lifestyle and Business, materi Seminar Internasional Pariwisata Halal di Bandung dan Indonesia International Halal Lifestyle Conference di Jakarta, situs internet serta printout panduan wisata halal dari Kementerian Pariwisata Republik Indonesia serta studi kepustakaan dari Dinas Pariwisata dan Kebudayaan Kota Batam, Majelis Ulama Indonesia (MUI) Kota Batam dan arsip kesekretariatan beberapa asosiasi pariwisata di Kota Batam. Data sekunder dimaksudkan untuk melengkapi data primer sehingga diharapkan dapat menambah data yang tidak terdeteksi. 


\section{HASIL DAN PEMBAHASAN Analisis Potensi Atraksi Wisata Halal Di Kota Batam}

Potensi wisata di Kota Batam telah dipetakan oleh Dinas Pariwisata dan Kebudayaan menjadi sembilan jenis wisata dengan masing-masing potensi unggulannya, antara lain:

1. Wisata Budaya (Tari Zapin, Kompang, Gasing, Mak Yong);

2. Wisata Bahari (Pulau Abang, Pantai Melur, Pantai Nongsa, Pulau Putri, Jembatan Barelang, Pantai Dendang Melayu, Pulau Belakang Padang, Pantai Mirota, Pantai Melayu);

3. Wisata Olahraga (Golf, Jetski, Banana Boat, Parasailing);

4. Wisata Belanja (Kawasan Jodoh, Kawasan Nagoya, BCS Mall, Nagoya Hill Mall, Mega Mall, Kepri Mall, Kek Pisang Villa, Kek Buah Naga Aroma, Bingka Bakar Nayadam);

5. Wisata Sejarah (Rumah Melayu Limas Potong, Makam Raja Nong Isa, Camp Kemanusiaan Vietnam);

6. Wisata Kuliner (Laksa, Lempok Durian, Nasi Lemak, Otak-Otak, Teh Tarik, Teh Obeng, Seafood, Kuliner Barat);

7. Wisata Religi (Masjid Agung Batam, Masjid Jabal Arafah, Masjid Cheng Ho, Patung Dewi Kwan Im, Vihara Duta Maytrea, Pura Agung Amertha Buana, GPIB Emmanuel);

8. Wisata Perkebunan (Hutan Bakau Nongsa, Kebun Buah Naga, Kebun Bunga Rossela, Hutan Wisata Mata Kucing);

9. MICE (Meeting, Incentive, Convention, Exhibition).

Berdasarkan panduan umum kriteria destinasi wisata halal, pertunjukan seni, budaya dan atraksi wisata lainnya di Kota Batam dapat dipastikan tidak ada yang melanggar dan bertentangan dengan nilai-nilai Islam karena seni budaya yang ditampilkan berlandaskan adat Melayu dan berunsur nilai-nilai agama Islam sehingga sangat mendukung konseptual dari atraksi wisata halal. Selain itu disebutkan pula bahwa sebagian besar destinasi wisata di Kota Batam umumnya sudah dilengkapi dengan fasilitas rumah ibadah terutama masjid atau musholla.

Dari sisi ketersediaan makanan dan minuman halal dapat dikatakan bahwa sudah semua destinasi wisata menyediakan warung atau rumah makan yang menjual makanan dan minuman halal meskipun belum seluruhnya tersertifikasi oleh LPPOM-MUI Provinsi Kepulauan Riau. Secara umum dapat dikatakan bahwa atraksi atau pertujukan wisata dan daya tarik wisata sudah dalam kondisi yang siap mendukung pengembangan wisata halal di Kota Batam.

\section{Analisis Aksesibilitas}

Aksesibilitas pariwisata terdiri dari dimensi informasi pariwisata halal dan keterjangkauan lokasi destinasi wisata, dari 98 wisatawan yang dimintai tanggapannya melalui kuesioner bahwa $40 \%$ responden menjawab baik, $26 \%$ menjawab netral, 23\% menjawab sangat baik. Sehingga pernyataan Mudah Mendapatkan Informasi Halal setelah dijumlah dalam pengukuran skala likert mendapatkan nilai 366 dengan presentase $73,2 \%$ yang berarti masuk pada kategori baik. Pernyataan lokasi destinasi wisata daya tarik wisata di Kota Batam mudah dijangkau dan diakses $44 \%$ responden menjawab baik, 34\% responden menjawab sangat baik, $15 \%$ responden menjawab netral dan sisanya responden menjawab tidak baik dan sangat tidak baik, setelah dijumlah dalam pengukuran skala likert 
mendapatkan nilai 403 dengan presentase 80,6\% menunjukan bahwa aksesibilitas pariwisata di Kota Batam sudah dalam kondisi yang sangat baik. Wisatawan sudah sangat mudah mendapatkan informasi yang berkaitan dengan halal baik secara online maupun offline. Informasi halal yang tersedia secara online dapat diakses pada situs resmi milik Majelis Ulama Indonesia Provinsi Kepulauan Riau atau Kota Batam pada laman LPPOM-MUI. Wisatawan dapat melihat referensi restoran atau rumah makan yang sudah bersertifikasi halal. Sedangkan informasi halal lainnya seperti akomodasi halal, spa halal dan biro perjalanan wisata halal sejauh ini belum tersedia karena belum ada yang memiliki sertifikasi halal.

Aspek lainnya yaitu berkaitan dengan keterjangkauan lokasi daya tarik wisata di Kota Batam bahwa 43\% responden menjawab baik, 19\% responden menjawab tidak baik, $17 \%$ responden menjawab netral, $16 \%$ responden menjawab sangat baik dan sisanya menjawab sangat tidak baik. Sehingga pernyataan tersedia transportasi lokal menuju daya tarik wisata setelah dijumlah dalam pengukuran skala likert mendapatkan nilai 348 dengan presentase $69,6 \%$ yang berarti masuk pada kategori baik. Dapat disimpulkan bahwa destinasi wisata di daerah Kota Batam mudah untuk diakses karena kondisi infrastruktur seperti; jalan raya, jembatan, moda transportasi darat dan laut, akses internet, listrik. dan air bersih sudah tersedia dan dalam kondisi yang memadai. Tersedia pula pilihan transportasi lokal seperti; bus, mini bus, elf, van, mobil pribadi, motor, speedboat, kapal feri, pompong, dan perahu nelayan menuju destinasi wisata namun dengan sistem pemesanan karena tidak ada transportasi umum yang melayani rute langsung menuju destinasi wisata.

\section{Analisis Amenitas}

Variabel amenitas terdiri dari dimensi akomodasi, restoran, biro perjalanan wisata dan jasa pramuwisata. Dari 98 wisatawan yang dimintai tanggapannya melalui kuesioner bahwa $49 \%$ responden menjawab baik, $28 \%$ menjawab sangat baik, $19 \%$ menjawab netral. Sehingga pernyataan tersedia fasilitas untuk bersuci di akomodasi setelah dijumlah dalam pengukuran skala likert mendapatkan nilai 400 dengan presentase $80 \%$ yang berarti pada kategori baik.

Terkait pernyataan tersedia fasilitas atau sarana yang memudahkan untuk beribadah di akomodasi, diketahui bahwa 48\% responden menjawab baik, $25 \%$ responden menjawab sangat baik, $21 \%$ responden menjawab netral, $6 \%$ responden menjawab tidak baik dan tidak ada responden yang menjawab sangat tidak baik. setelah dijumlah dalam pengukuran skala likert mendapatkan nilai 391 dengan presentase $78,2 \%$ yang berarti masuk pada kategori baik.

Dari 98 responden diketahui bahwa $48 \%$ responden menjawab baik, $29 \%$ responden menjawab sangat baik, $17 \%$ responden menjawab netral, $6 \%$ responden menjawab tidak baik dan tidak ada responden yang menjawab sangat tidak baik. Sehingga pernyataan terjamin ke-halalan makanan dan minuman dengan adanya jaminan atau sertifikat halal dari MUI setelah dijumlah dalam pengukuran skala likert mendapatkan nilai 400 dengan presentase $80 \%$ yang berarti masuk pada kategori baik.

Dari 98 responden diketahui bahwa 53\% responden menjawab baik, 25\% responden menjawab netral, $20 \%$ responden menjawab sangat baik dan sisanya responden menjawab tidak baik. Sehingga pernyataan terjaga lingkungan yang sehat dan bersih di tempat usaha penyedia makanan dan minuman setelah dijumlah 
dalam pengukuran skala likert mendapatkan nilai 390 dari dengan presentase $78 \%$ yang berarti masuk pada kategori baik.

Dari 98 responden diketahui bahwa 49\% responden menjawab baik, $25 \%$ responden menjawab netral, $20 \%$ responden menjawab sangat baik, $6 \%$ responden menjawab tidak baik dan tidak ada responden yang menjawab sangat tidak baik. Sehingga pernyataan Biro perjalanan wisata menyediakan paket perjalanan sesuai dengan kriteria umum pariwisata halal setelah dijumlah dalam pengukuran skala likert mendapatkan nilai 383 dengan presentase $76,6 \%$ yang berarti masuk pada kategori baik.

Dari 98 responden diketahui bahwa 47\% responden menjawab baik, 27\% responden menjawab netral, 17\% responden menjawab sangat baik, 9\% responden menjawab tidak baik dan tidak ada responden yang menjawab sangat tidak baik. Sehingga pernyataan pemandu wisata memahami dan mampu melaksanakan nilainilai halal dalam menjalankan tugasnya setelah dijumlah dalam pengukuran skala likert mendapatkan nilai 373 dengan presentase $74,6 \%$ yang berarti masuk pada kategori baik.

Meskipun belum ada hotel yang secara legal formal bersertifikasi halal di Kota Batam namun secara umum akomodasi sudah banyak menerapkan aspekaspek yang mengarah pada kriteria hotel halal seperti menyediakan fasilitas bersuci di dalam kamar mandi hotel, menyediakan air mengalir yang dapat digunakan untuk sarana berwudu, pengecekan kebersihan secara rutin, menyediakan arah kiblat dan melayani permintaan fasilitas ibadah lainnya seperti sajadah, tasbih dan Alquran. Selain itu sebagian besar akomodasi di Kota Batam sudah dilengkapi dengan fasilitas restoran utama hotel yang menyajikan makanan dan minuman yang sudah tersertifikasi halal oleh LPPOM-MUI Provinsi Kepulauan Riau.

Usaha penyedia makanan dan minuman seperti restoran, rumah makan, pujasera, foodcourt, kafe dan kedai di Kota Batam beberapa sudah tersertifikasi halal oleh LPPOM-MUI Provinsi Kepulauan Riau. Berdasarkan hasil wawancara mendalam dan diskusi Peneliti dengan informan dari Perhimpunan Hotel dan Restoran Indonesia (PHRI) Kota Batam, hal tersebut ditunjang dengan tingkat kesadaran para pengusaha makanan dan minuman terhadap sertifikasi halal yang cukup tinggi sehingga banyak para pengusaha makanan dan minuman yang secara mandiri mengurus sertifikasi halal tersebut. Dikatakan pula bahwa sertifikasi halal dilakukan karena permintaan konsumen terhadap makanan dan minuman halal yang cenderung selalu meningkat. Sehingga dengan adanya sertifikasi halal yang dikeluarkan oleh LPPOM-MUI maka sudah dapat dipastikan bahwa usaha penyedia makanan dan minuman tersebut selalu memperhatikan kebersihan lingkungan dan menjaga kesehatan makanan dan minumannya.

Berdasarkan informan dari Asosiasi Perusahaan Perjalanan Indonesia (ASITA) Provinsi Kepulauan Riau bahwa belum terdapat biro perjalanan wisata bersertifikasi halal di Kota Batam. Sampai saat ini belum ada biro perjalanan wisata yang secara khusus membuat paket-paket perjalanan wisata halal. Namun mereka siap menyediakan paket perjalanan halal jika diminta (by request).

Meskipun belum menjadi biro perjalanan wisata halal namun pada umumnya paket perjalanan wisata yang dibuat sudah mengarah pada kriteria biro perjalanan wisata halal karena komponen paket perjalanan yang ditawarkan selalu memperhatikan jadwal salat dengan berhenti di masjid atau musala untuk mempersilakan wisatawan yang ingin menunaikan ibadah. Selain itu biro 
perjalanan wisata dapat singgah dan memilih restoran atau rumah makan yang sudah bersertifikasi halal. Asosiasi Perusahaan Perjalanan Indonesia (ASITA) Provinsi Kepulauan Riau sampai dengan saat ini belum melakukan rekap terhadap daftar restoran halal. Sehingga pemilihan restoran atau tempat makan dalam itinerary hanya berdasarkan referensi dari website LPPOM-MUI dan dengan alasan sudah merasa hafal dengan restoran atau tempat makan bersertifikasi halal di Kota Batam. Sedangkan untuk pemilihan penginapan bagi para wisatawan Muslim, biro perjalanan wisata biasa memilih hotel atau penginapan yang sudah menjalin kerjasama dengan biro perjalanan yang dipercaya mampu memenuhi kebutuhan wisatawan Muslim selama berada di penginapan.

Berdasarkan informan dari Himpunan Pramuwisata Indonesia (HPI) Kota Batam diketahui bahwa jumlah anggota Himpunan Pramuwisata Kota Batam saat ini berjumlah 340 orang dimana 220 orang telah tersertifikasi dan 120 orang lainnya sedang menunggu proses sertifikasi profesi. Fungsi dari sertifikasi atau lisensi bagi pramuwisata adalah agar pramuwisata memiliki kompetensi keahlian memandu wisata dan kualifikasi kerja yang sesuai dengan standar dan kode etik kepramuwisataan dunia. Pramuwisata yang sudah memiliki sertifikasi profesi berarti telah mengikuti proses uji kompetensi sehingga siap bekerja langsung di dunia industri sesuai dengan bidang keahliannya yaitu sebagai seorang pemandu wisata.

Dalam melakukan pekerjaannya, seorang pemandu wisata dituntut agar dapat menyesuaikan diri dengan kondisi perjalanan dan itinerary yang telah dibuat oleh tour operator. Sehingga dibutuhkan kemampuan seperti memprediksi waktu, memberikan informasi umum hingga spesifik tentang suatu objek dengan akurat dan mampu menjaga kondisi wisatawan selama proses perjalanan berlangsung. Dari pengamatan penulis pemandu wisata yang sudah memiliki sertifikasi profesi semuanya telah menerapkan SOP sesuai kriteria yang harus diperhatikan oleh pemandu wisata halal antara lain:

1. Melaksanakan nilai-nilai halal dalam menjalankan tugas;

2. Berakhlak baik, komunikatif, ramah, jujur dan bertanggungjawab;

3. Berpenampilan rapi, sopan sesuai nilai dan etika Islam;

4. Tidak mengarahkan kepada hal-hal yang bertentangan dengan prinsip wisata halal;

5. Memiliki sertifikasi pemandu wisata;

6. Memiliki kompetensi kerja sesuai standar profesi berlaku.

\section{Analisis Kelembagaan Pariwisata}

Analisis kelembagaan pariwisata membahas tiga dimensi utama yang meliputi organisasi pariwisata, pemberdayaan masyarakat dan pemasaran pariwisata yang semuanya dilihat dari perspektif wisata halal. Terkait hal tersebut Peneliti telah melakukan wawancara mendalam dan diskusi dengan Kepala Bidang Sarana dan Objek Wisata Dinas Pariwisata dan Kebudayaan Kota Batam yang menghasilkan beberapa kesimpulan sebagai berikut:

1. Organisasi Pariwisata 
Kriteria untuk organisasi pariwisata adalah 1) Terdapat sistem yang mendukung sertifikasi halal, 2) Kelembagaan profesional atau pemerintah yang mendukung sertifikasi halal bagi pelaku industri, 3) Terdapat organisasi seperti KOMPEPAR atau POKDARWIS di destinasi. Sebagian besar destinasi wisata di Kota Batam dikelola oleh pihak swasta dan masyarakat lokal. Dinas Pariwisata dan Kebudayaan Kota Batam memberikan kewenangan kepada pihak swasta dan masyarakat untuk mengelola dan membuat manajemen sendiri di kawasan yang dikelolanya sesuai dengan kebutuhan dan kondisi destinasi tersebut. Pemerintah daerah menyadari bahwa diperlukan partisipasi aktif dari pihak swasta dan masyarakat untuk mendukung aktivitas wisata di destinasi. Dengan dibentuk Kelompok Sadar Wisata (POKDARWIS) di setiap kecamatan sesuai dengan arahan dari Kementerian Pariwisata, pemerintah daerah dalam hal ini Dinas Pariwisata dan Kebudayaan Kota Batam berperan sebagai pengarah kebijakan sekaligus melaksanakan fungsi pengawas terhadap manajemen di setiap destinasi wisata.

Sejauh ini meskipun kebijakan resmi yang dikeluarkan oleh pemerintah daerah terkait implementasi wisata halal di Kota Batam belum ada. Namun telah dilakukan soft promotion dan pengenalan materi tentang wisata halal kepada para akademisi, praktisi, asosiasi dan tokoh masyarakat dalam berbagai pertemuan seperi pelatihan, seminar, sosialisasi, rapat konsolidasi dan rapat kerja. Selain itu berdasarkan informasi disebutkan bahwa Dinas Pariwisata dan Kebudayaan Kota Batam sudah melakukan kerjasama dengan Dinas Kesehatan dan lembaga non-pemerintah seperti LPPOM-MUI, Lembaga Sertifikasi Usaha dan Lembaga Sertifikasi Profesi yang juga turut membantu melaksanakan sertifikasi halal.

2. Pemberdayaan Masyarakat

Program pemberdayaan kepada masyarakat lokal sudah dilakukan sejak lama dan tidak hanya berlaku untuk sektor pariwisata saja. Setiap usaha sedapat mungkin melibatkan masyarakat lokal atau warga setempat untuk bekerja sesuai dengan keahlian atau kompetensi yang dimiliki. Selain itu sistem pemberdayaan masyarakat lokal di destinasi wisata dilakukan melalui pertemuan rutin setiap dua bulan sekali dengan perwakilan masyarakat yang diwakili oleh anggota Kelompok Sadar Wisata, dimana tujuan utamanya adalah untuk mengkampanyekan kota Batam sebagai salah satu destinasi wisata halal.

Sejauh ini penduduk asli Batam sangat terbuka terhadap aktivitas pariwisata di daerahnya selama tidak melanggar norma agama dan adat istiadat setempat. Masyarakat lokal secara langsung maupun tidak langsung telah merasakan dampak positif dari kegiatan pariwisata yang dibuktikan dengan meningkatnya pendapatan masyarakat yang berada di sekitar lokasi wisata. Masyarakat lokal menyambut aktivitas pariwisata di daerahnya dengan memanfaatkan peluang yang ada seperti; menjual makanan dan minuman, menjual oleh-oleh, menjadi pemandu wisata lokal, menyewakan penginapan, menjadi juru foto, dan penyewaan transportasi lokal.

3. Pemasaran Pariwisata

Implementasi wisata halal sangat didukung oleh Walikota Batam, dalam beberapa pidatonya terkait kepariwisataan walikota selalu memerintahkan agar segera melakukan kajian pengembangan wisata halal di Kota Batam. Meskipun Peraturan Daerah Kota Batam tentang Wisata Halal belum diterbitkan, namun 
sudah dilakukan beberapa aktivitas pengenalan wisata halal pada setiap pertemuan resmi antara Dinas Pariwisata dan Kebudayaan Kota Batam, asosiasi pariwisata, akademisi pariwisata dan masyarakat Kota Batam.

Meskipun Belum ada kelembagaan khusus dari pemerintah daerah yang menangani pemasaran wisata halal tetapi promosi destinasi wisata halal harus sudah dilakukan dan disosialisasikan, kota Batam harus memposisikan sebagai destinasi wisata halal. Hal pertama yang harus dilakukan adalah segera membuat Peraturan Daerah tentang wisata halal, sehingga tim percepatan pemasaran wisata halal dapat segera dibentuk. Saat ini Dinas Pariwisata dan Kebudayaan Kota Batam sedang menunggu dikeluarkannya Peraturan Daerah tentang Wisata Halal yang masih dalam proses perumusan antara Pemerintah Kota dan Dewan Perwakilan Rakyat Daerah (DPRD).

\section{Upaya Kota Batam Dalam Mengembangkan Destinasi Wisata Halal}

Lebih jelasnya mengenai upaya mengembangkan destinasi wisata halal di Kota Batam peneliti sampaikan dalam bentuk analisis SWOT (strength, weakness, opportunity, threat) yang dapat dijadikan sebagai bahan analisis kebijakan bagi para pembuat kebijakan dan pengambil keputusan di lingkungan kepariwisataan Kota Batam:

1. Kekuatan (Strength)

a. Letak geografis Kota Batam yang merupakan daerah perbatasan (cross border) antar negara dan berada pada jalur perdagangan internasional Selat Malaka.

b. Terdapat potensi daya tarik wisata mulai dari alam, budaya dan buatan manusia yang dibagi menjadi sembilan kategori jenis wisata yaitu budaya, religi, bahari, sejarah, olahraga, belanja, kuliner, perkebunan dan MICE. Semuanya tidak bertentangan dengan kriteria destinasi wisata halal.

c. Aksesibilitas jalur udara dan laut dari dan menuju Kota Batam sangat mudah bahkan sudah tersedia penerbangan internasional langsung dari dan menuju Kuala Lumpur, Malaysia.

d. Amenitas pariwisata seperti hotel, restoran dan transportasi beberapa sudah memiliki sertifikat halal.

e. Terdapat kelembagaan yang mendukung sertifikasi halal bagi pelaku industri pariwisata.

f. Terdapat organisasi pariwisata di lingkup Masyarakat di Destinasi Wisata.

g. Masyarakat Kota Batam sangat memegang teguh adat istiadat budaya Melayu. Budaya Melayu sendiri adalah adat yang kental dengan nilai-nilai keislaman.

h. Adanya dukungan dari Pemerintah Kota Batam dan Majelis Ulama Indonesia Kota Batam kepada seluruh pelaku usaha kuliner untuk melakukan sertifikasi halal produk usahanya.

2. Kelemahan (Weakness)

a. Kurang optimalnya pengelolaan serta minimnya fasilitas toilet umum dan air bersih masih menjadi masalah di beberapa lokasi destinasi wisata sehingga cenderung mengecewakan wisatawan.

b. Beberapa restoran di Kota Batam belum menerapkan pemisahan antara dapur untuk memasak masakan halal dan non-halal sehingga kehalalannya diragukan. 
c. Dewan Syariah Nasional (DSN) Majelis Ulama Indonesia Kota Batam sebagai lembaga otonom yang mempunyai wewenang melakukan sertifikasi kepada usaha jasa pariwisata seperti hotel, biro perjalanan wisata, spa dan sauna serta usaha jasa pariwisata lainnya belum optimal melakukan upaya sertifikasi halal.

d. Minimnya pengetahuan sebagian besar masyarakat dan pelaku industri pariwisata di Kota Batam terhadap konseptual wisata halal, sehingga masih banyak yang mempersepsikan bahwa wisata halal sebagai kegiatan wisata yang bersifat parsial.

3. Peluang (Opportunity)

a. Pertumbuhan jumlah wisatawan Muslim dunia ke Indonesia akan diprediksi tumbuh menjadi 5 juta wisatawan Muslim mancanegara dan 260 juta wisatawan Muslim nusantara pada tahun 2020.

b. Kota Batam menjadi fokus pengembangan destinasi wisata halal unggulan bersama dengan daerah potensial lainnya yaitu Sumatera Barat, Aceh, Bandung, Jakarta dan Lombok.

c. Beberapa pasar Muslim mancanegara wilayah Asia di Indonesia seperti Singapura, Malaysia, India dan Tiongkok sudah lebih dulu menjadi pasar pariwisata paling potensial di Kota Batam.

d. Ditetapkannya Batam sebagai pintu masuk utama wisatawan mancanegara di bagian barat Indonesia dan menjadi yang ketiga terbesar setelah Bali dan Jakarta perihal kontribusi jumlah kunjungan wisatawan mancanegara ke Indonesia.

e. Tingkat permintaan (demand) wisatawan mancanegara ke Indonesia terhadap konsumsi halal yang relatif tinggi terutama dari negara-negara yang mayoritas penduduknya Muslim.

f. Investasi, devisa, pendapatan asli daerah sektor pariwisata dan pendapatan masyarakat lokal akan meningkat seiring dengan berkembangnya kegiatan pariwisata di Indonesia.

4. Ancaman (Threat)

a. Belum adanya regulasi atau kebijakan dalam bentuk perundang-undangan nasional tentang wisata halal, sehingga menyulitkan para pembuat kebijakan yang ingin mengembangkan wisata halal di daerahnya.

b. Kurangnya sosialisasi tentang pemahaman wisata halal kepada masyarakat sehingga banyak yang berpandangan bahwa wisata halal hanya diperuntukan bagi kalangan tertentu dan dianggap mendiskriminasikan kalangan lainnya.

c. Negara - negara seperti Hongkong, Korea, Jepang, Thailand, Singapura dan Cina telah mengembangkan wisata halal.

\section{Analisis Strategi Kebijakan}

Berdasarkan pembahasan dan analisis hasil penelitian menggunakan analisis SWOT, berikut strategi kebijakan yang dapat digunakan sebagai bahan pertimbangan untuk mengembangkan wisata halal di Kota Batam. yang dapat dilihat pada tabel di bawah ini: 
Tabel 1

Strategi Kebijakan Pengembangan Wisata Halal di Kota Batam

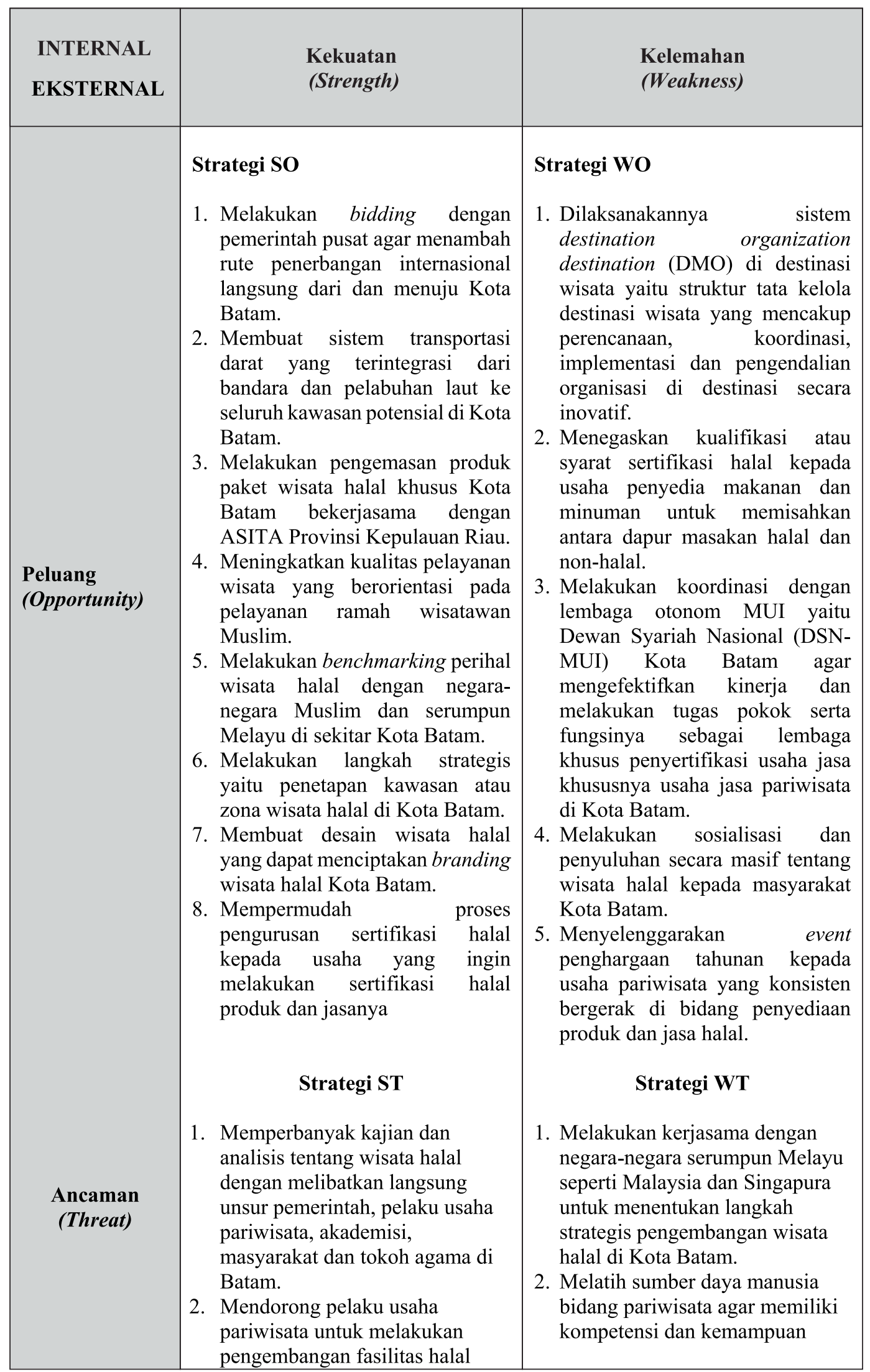




\begin{tabular}{|l|l|l|}
\hline & $\begin{array}{l}\text { pada produk dan jasa usaha } \\
\text { pariwisatanya. }\end{array}$ & $\begin{array}{l}\text { kerja yang bersaing dengan } \\
\text { asing. }\end{array}$ \\
& 3. $\begin{array}{l}\text { Menyediakan fasilitas } \\
\text { pendukung kegiatan wisata halal } \\
\text { seperti akomodasi, biro }\end{array}$ & $\begin{array}{l}\text { Membentuk tim percepatan } \\
\text { pengembangan wisata halal pada } \\
\text { tingkat Kota Batam yang }\end{array}$ \\
$\begin{array}{l}\text { perjalanan wisata, spa dan sauna } \\
\text { yang sesuai dengan panduan } \\
\text { umum dan kriteria halal. }\end{array}$ & $\begin{array}{l}\text { perkoordinasi dengan tim } \\
\text { percepatan wisata halal pusat. } \\
\text { 4elakukan koordinasi dan } \\
\text { diskusi lintas agama mengenai } \\
\text { pemahaman tentang wisata halal pemasaran dan } \\
\text { pang lebih komprehensif. }\end{array}$ & $\begin{array}{l}\text { promosi wisata halal Kota Batam } \\
\text { melalui sistem digitalisasi } \\
\text { sebagai bentuk apresiasi pada } \\
\text { program Kementerian Pariwisata. }\end{array}$ \\
\hline
\end{tabular}

\section{SIMPULAN}

Dari uraian hasil dan pembahasan mengenai Analisis Pengembangan Potensi Destinasi Wisata Halal di Kota Batam, maka dapat tarik kesimpulan panduan umum dan kriteria halal bagi wisatawan dan industri usaha produk atau jasa pariwisata seperti akomodasi, usaha penyedia makanan dan minuman, biro perjalanan wisata, jasa pramuwisata dan transaksi wisata mengaktualisasikan nilainilai ke-Islaman pada produk, pelayanan dan pengelolaannya sesuai dengan ketentuan agama Islam. Meskipun begitu, segala bentuk produk dan jasa pariwisata yang berkriteria halal adalah bersifat universal sehingga dapat diimplementasikan dan dinikmati oleh semua kalangan. Karena pada prinsipnya segala sesuatu yang halal sudah pasti memperhatikan aspek-aspek seperti kesehatan, keamanan, kebaikan, keselamatan, keadilan dan style yang seluruhnya merupakan bagian dari kebutuhan umat manusia.

Potensi atraksi, aksesibilitas, amenitas dan kelembagaan pariwisata seluruhnya sudah dalam kondisi yang baik dan siap untuk mendukung pengembangan destinasi wisata halal di Kota Batam. Seperti potensi daya tarik wisata alam, budaya dan buatan manusia yang sudah dikategorikan menjadi sembilan jenis wisata unggulan Kota Batam. Aksesibilitas jalur darat, laut dan udara sudah sangat memadai dan mudah untuk diakses. Amenitas pariwisata seperti akomodasi, restoran halal, sarana ibadah, sarana pendidikan, sarana kesehatan, sarana pusat perbelanjaan, sarana olahraga dan sarana penunjang lainnya sudah tersedia dalam berbagai pilihan. Selain itu, kelembagaan pariwisata juga sudah memiliki sistem yang saling bersinergi antara pemerintah daerah, pelaku industri pariwisata dan masyarakat.

Secara keseluruhan Kota Batam layak dikembangkan menjadi destinasi wisata halal. Namun, masih dibutukan komitmen dan koordinasi dengan berbagai pihak dan harus didukung pula dengan kesiapan sumber daya manusia yang berkompeten di bidang pariwisata serta melakukan pemasaran dan branding yang tepat agar pengembangan wisata halal di Kota Batam berjalan secara optimal. 


\section{DAFTAR PUSTAKA}

Ahmad, H. (2016). Pedoman Usaha Hotel Halal. Pada Seminar Internasional Pariwisata Halal. Bandung: Kementerian Pariwisata.

Albar, M. (2012). Kepulauan Riau: The Beauty of Nature an Essential Guide to Explore Kepri. Cetakan Ke-1 Juli 2012. www.kepritourism.com.

Arintawati, M. (2016). Konsep dan Sertifikasi Restoran Halal. Pada Seminar Internasional Pariwisata Halal. Bandung: Lembaga Pengkajian Pangan, ObatObatan dan Kosmetika Majelis Ulama Indonesia (LPPOM-MUI).

Ashari, A. (2016). Pengaruh Islamic Attribute of Destination Terhadap Keputusan Berkunjung (Survei pada Wisatawan Muslim Malaysia yang Berkunjung ke Kota Bandung). Skripsi diterbitkan. Bandung: Universitas Pendidikan Indonesia.

Asisten Deputi Penelitian dan Pengembangan Kebijakan Kepariwisataan, Deputi Bidang Pengembangan Kelembagaan Kepariwistaan. (2015). Kajian Pengembangan Wisata Syariah: Studi Kasus Aceh dan Manado. Jakarta: Kementerian Pariwisata.

Astiwara, E. M. (2016). Panduan Pariwisata Halal. Pada Seminar Internasional Pariwisata Halal. Bandung: Dewan Syariah Nasional (DSN-MUI).

Bawazir, T. (2012). Panduan Wisata Syariah: Wisata Nyaman, Ibadah Lancar. Cetakan Ke-1 Juni 2013. Jakarta Pustaka Al-Kautsar.

BPS Kota Batam. (2016). Direktori Hotel dan Jasa Akomodasi Lainnya Kota Batam 2016. Diakses tanggal 17 Maret 2017. Dari https://batamkota.bps .go.id/website/pdf_publikasi/Direktori-Hotel-dan-Jasa-Akomodasi-LainnyaKota-Batam-2016.pdf.

BPS Kota Batam. (2016). Kota Batam Dalam Angka: Batam City in Figures. BPS Kota Batam: Katalog BPS 1102.001.2171. Publikasi: 21.71.16.1.

BPS Kota Batam. (2016). Kota Batam Dalam Angka 2016. Diakses tanggal 17 Maret 2017. Dari https:// batamkota.bps.go.id/linkTabelStatis/view/id.48.

Buhalis, D., \& Cooper, C. (1998). Small and medium sized tourism enterprises at the destination. Embracing and managing change in tourism: International case studies, 329, 329-351

Chookaew, S., Chanın, O., Charatarawat, J., Sriprasert, P., \& Nimpaya, S. (2015). Increasing Halal Tourism Potential at Andaman Gulf in Thailand for Muslim Country. Journal of Economics, Business and Management, 3(7), 739-741.

Creswell, J. W. (2010). Research Design: Pendekatan Kualitatif, Kuantitatif dan Mixed. Cetakan Ke-1 2010. Yogyakarta: Pusaka Pelajar.

Halal MUI Kepri. (2017). Restoran Hotel Halal Kota Batam. Diakses tanggal 18 Maret 2017. Dari http://www.halalmuikepri.com/restoran-hotel-batam/. 
Hamzah, M., \& Yudiana, Y. (2015). Analisis Komparatif Potensi Industri Halal dalam Wisata Syariah dengan Konvensional. Diakses tanggal 19 Desember 2016. Dari http://catatan-ek18.blogspot.co.id.

Highlights, U. T. (2016). UNWTO Tourism Highlights (2016). Edition. URL: www. unwto. org.

International Travel Week Abu Dhabi. (2016). The World Halal Tourism Award 2016 Categories. Diakses tanggal 28 Februari 2017. Dari http://itwabudhabi.com/halal-awards/2016-winners.htm.

Kovjanic, G. (2014). Islamic Tourism as a Factor of the Middle East Regional Development. Diakses tanggal 25 November 2016. Dari http://www. dgt.uns.rs/turizam/arhiva/vol_1801_4.pdf.

Nirwandara, S. (2016). Road to Halal Tourism and Halal Life Style. Pada Seminar Internasional Pariwisata Halal. Bandung: Institut Teknologi Bandung.

Priyadi, U. (2016). Pariwisata Syariah Prospek dan Perkembangan. Yogyakarta: UPP STIM YKPN.

Rahyudin, dkk. (2016). Direktori Hotel dan Jasa Akomodasi Lannya Kota Batam. BPS Kota Batam: Katalog BPS 130543.2171. Publikasi: 2171.15.01.

Sofyan, R. (2012). Prospek Bisnis Pariwisata Syariah. Cetakan Ke-1 Desember 2012. Jakarta: Buku Republika.

Sucipto, H., \& Andayani, F. (2014). Wisata Syariah: Karakter, Potensi, Prospek dan Tantangannya. Cetakan Ke-1 Juni 2014. Jakarta: Grafindo.

Widagdyo, K. (2015). Analisis Pasar Pariwisata Indonesia. The Journal of Tauhidinomics Vol. 1 No. 1 (2015): 73-80. Dari https://www.google.co.id $/$ search? site $=\&$ source $=$ hp \&q $=$ analisis + pasar + pariwisata + halal + Indonesia\&o $\mathrm{q}=$ analisis+pasar+pariwisata+halal+Indonesia.

Yahya, A. (2016). Kebijakan Pengembangan Pariwisata Halal Indonesia. Pada Indonesia International Halal Life Style Conference. Jakarta: Kementerian Pariwisata. 